速＼cjkstart報

論文受付

2011 年 5 月20日

論文受理

2011 年 6 月7昌

Code No. 890

\section{X 線検出器(イメージングプレート)の放射能污染に対する} 効果的な除染方法の提案

\author{
西原貞光・林 裕晃
}

徳島大学大学院ヘルスバイオサイエンス研究部

\section{はじめに}

2011 年 3 月に起こった東日本大震災によって, 多 くの住民が被姼すると同時に，多くの施設が被害に 見舞われた。さらに福島第一原子力発電所の事故に よって, 関東東北地方の広範囲に放射性同位元素 (以 下， RI)が飛散した。各都道府県別の RI の飛散状況 は，首相官邸のホームページで一般向けに公開され ている11)。このような広範囲に飛散する RI は，キセノ ン等の希ガスや揮発性のヨウ素, セシウム $(\mathrm{Cs})$ の同 位体である ${ }^{2)}$ ，それらの化学的性質を考慮すると，医 療施設等の $\mathrm{X}$ 線撮影室まで拡散していることが想定 される，最終的に原発事故が収束し，新たな RI の放 出がなくなった時点で問題となるのは, 半減期が長い ${ }^{134} \mathrm{Cs}$ (2 年) と ${ }^{137} \mathrm{Cs}(30$ 年)であると考える。したがっ て，これらの核種による污染があった場合には抜本 的な解決をしなければならない.

同 3 月 18 日の時点で, メーカ側から「FCR 画像に
黒点が発生する件」という報告がなされるとともに, 現在でもいくつかの病院において同様の現象が発生 している。そこで，「CRを用いた環境モニタリング調 査研究班」が本学会において設置され, 全国で 60 施 設以上が協力・対処している.この研究班の目的は, 臨床の現場で利用しているイメージングプレート (IP) を使って， RI の飛散状況をモニタリングすることで あると考える.

一方, 各施設において実際に黒点が発生した場 合, メーカ側はカセッテや IP などタリーニングす るとともにIPを一時消去するように，ホームページ 上で勧めている3). しかし，どの程度のクリーニング で良いのか, その効果はどのくらいなのか, という具 体的なことについては議論されていない. 診療の妨 げとなる不要な画像情報を速やかに除去し, 安定し た画像の供給が可能となるようにすることが, 診療放 射線技師としての責務であると考える.

\title{
Effective Method for Decontaminating Radioactive X-ray Detectors (Imaging Plates)
}

\author{
Sadamitsu Nishihara and Hiroaki Hayashi \\ Institute of Health Biosciences, The University of Tokushima Graduate School \\ Received May 20, 2011; Revision accepted June 7, 2011; Code No. 890
}

\section{Summary}

Several hospitals have been observing black spots in medical images, and the radioisotopes (RIs) that cause the spots needs to be removed from the X-ray receptors. Our purpose is to show a flowchart for finding out under which conditions an imaging plate (IP) and other parts (for example, the cassette) are contaminated by RIs and to propose an effective method to remove them. The procedure follows. (1) Is RI activity low? (2) Are the surfaces of other parts contaminated? (3) Is the surface of the IP contaminated? (4) Are the insides of the other parts contaminated? To remove the adhered RIs, we applied a wipe test method using a wet type of chemical wiper. A certain hospital that observed black spots experimented with this method. As a result, the contaminated condition of the X-ray receptor was identified. In addition, we were able to remove the RIs from the IP. Therefore, our procedure is very effective for decontaminating adhered RIs from receptors.

Key words: X-ray detector, imaging plate, radioactive decontamination, wet-type of chemical wiper 


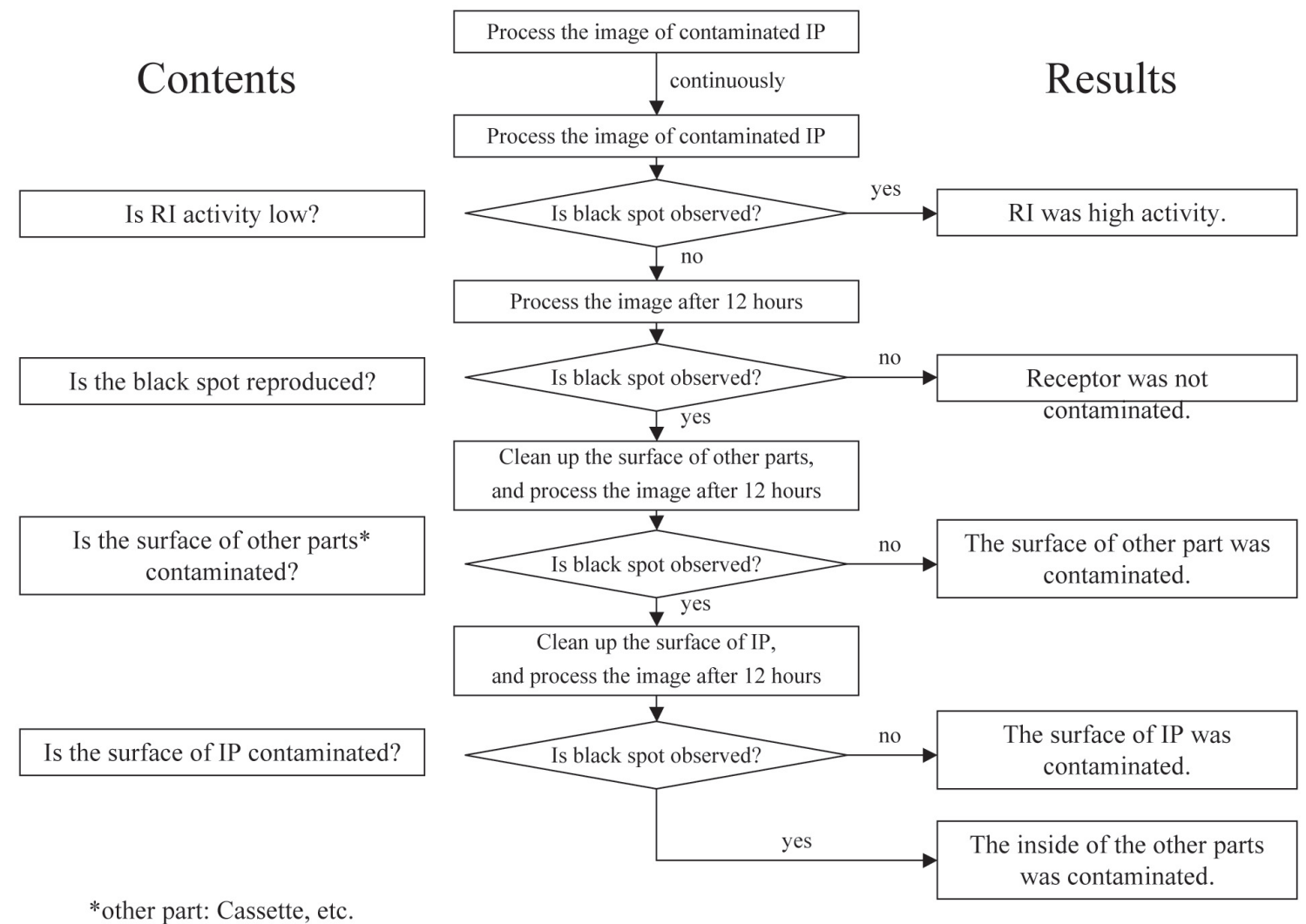

Fig. 1 Flowchart to find out the conditions of an imaging plate (IP) and other parts (for example, the cassette)

実際に臨床現場で黒点が発生した場合，早急かつ 効率的に解決することが望ましい.そこでわれわれ は，黒点が発生したときの具体的な除染のための手 順(流れ)と，市販の化学雑巾を使った簡易的かつ効 果的な除染方法を提案した。 また，この方法を実際 に適用し，その除染効果を確認できたので速報とし て事例報告を行う.

\section{1. 使用機器・器具}

化学雑巾：クイックルワイパー・ウェットシート(花王) ディジタル画像システム:FCR5501plus（富士フイル ム社)

\section{2. 提案する方法}

黒点が発生したとき，どこの部分にどういう状況で RIが付着しているかを，次の流れに沿って判断す る. 同様に，そのフローチャートを Fig. 1 に示す。こ こに記載する項目は，基本的にカセッテタイプでもビ ルトインタイプでも対応可能である. カセッテタイプ というのは, 従来の増感紙フィルム系と同じように, それ自体が持ち運び可能なものを指す。またビルトイ ンタイプについては，複数の IP を内蔵し，従来の フィルムチェンジャと同じような仕組みを持つものを
指す。

この除染方法を実施するにあたって，一応，メーカ 側にウェットタイプのクイックルワイパーを使用して 支障がないかどうかを確認しておくことを勧める。

\section{2-1＼cjkstart低濃度の RI であるかどうかを確認する}

黒点が出たIPを，臨床で採用している読み取り モードで処理する。そのとき，「2回連続」して読み取 る。この理由は，「もし低濃度の RI であるなら，露光 時間がほとんどない 2 枚目には黒点が出ない」ことに 基づく.

\section{2-2＼cjkstart再現性を確認する}

受像器を通常状態で約 12 時間保管した後, 同じ処 理を実施する。同じ位置に黒点が発生するかどうか を確認することで，再現性が判断できる.

\section{2-3 受像器上に RI が付着しているかどうかを確認} する

カセッテ(ビルトインタイプであれば装置の表面)を 化学雑巾で清掃した後, 通常状態のまま約 12 時間保 管し処理する。受像器内や IP に直接 RI が付着して いる場合では，黒点の位置や大きさ，濃度などに再 

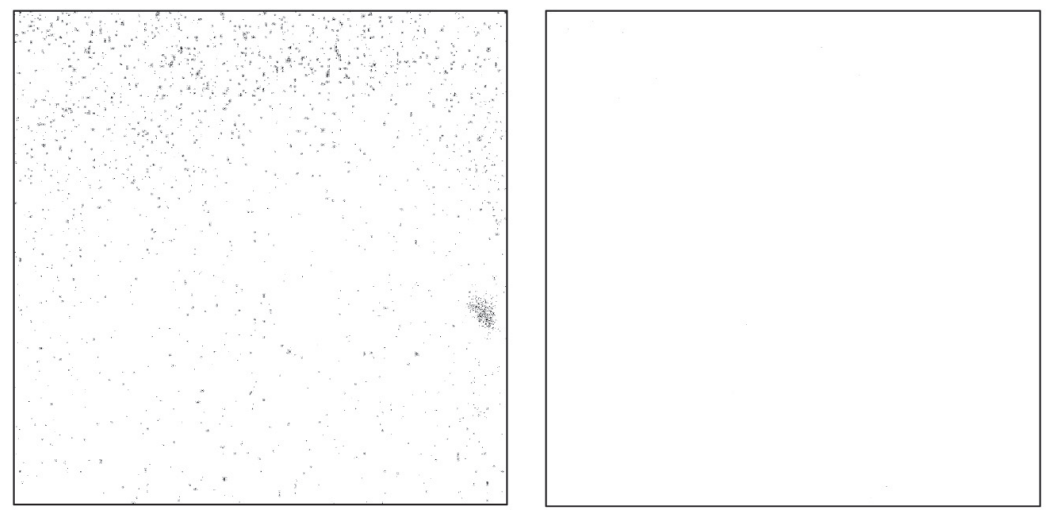

$a \mid b$

Fig. 2 Comparison of images of a contaminated IP (a) and decontaminated one (b).

The samples are based on the same IP, which was used for FCR5501. The exposure times were about 12 and 15 hours for (a) and (b), respectively.

現性のあることが予想される。

\section{2-4 受像器内部に RI が入り込んでいるかどうか を確認する}

カセッテから IP を取り出し(または装置表面を外し て), IPをクイックルワイパーで清掃する。清掃後, 12 時間程度保管して同処理を実施する。IPにRI が 付着していた場合，黒点が消失するか，他の場所に 移動するという現象が見られる可能性が高い.

ここまでの段階を実施した後においても黒点が発 生する場合には，カセッテ内(装置内)の裏側に RI が 付着していると考えられる。

ここで示す方法は，除染法を伝えるとともに，どの 部分が污染しているかを調査することに重点を置い ている。したがって，この通りに検証した場合，除染 作業は少なくとも2，3 日必要となる。一方，緊急性 を重視して除染業務を第一とするときには，上記のこ とをすべて一度に実施するべきである。

\section{3. 結果と考察}

今回提案する確認方法のどの段階においても，想 定外のことが起こったときには次のステップへ進んで はいけない。例えば，2-1による検査で高濃度の RI で污染していることが判明した場合，今回提案した ようなウェットタイプの化学雑巾を用いて清掃する と, 污染個所を広げるだけの結果となる可能性が高 い.したがって，この状態であると判断されるときに は，施設内に設置された放射線管理部門のスタッフ に相談し，早急な対処を検討することが必要である。

流れに沿って，どの状況でRIの污染が起こってい るかを確認するが，2-3 および 2-4 で除染に使う器具 は, ウェットタイプの化学雑巾(クイックルワイパー) である。林らはRI の付着した床面を化学雑巾で清掃 し，その拭き取り効率を検討した4)。その結果，ドラ イタイプのクイックルワイパーでは 1 往復で $3 \%$ 程度 しか拭き取ることができなかったが, ウェットタイプ
を用いたときには 1 回で約 $60 \%$ も拭き取ることができ たと報告している。今回，污染物質と想定している Cs はアルカリ金属であり，天然には一価の陽イオン として存在し, 希ガス状態の電子配置を取っている と考えられる5 . 本手法で使用したウェットタイプの 化学雑巾は水溶性の元素の除染に向いているので, 特にCs の除染に適している.

除染後には，除染された RI が化学雑巾に付着す る。管理区域外への持ち出し基準となる表面密度限 度は， $\beta$ 線放出核種では $40 \mathrm{~Bq} / \mathrm{cm}^{2}$ であることを考慮 し廃棄の判断を行う ${ }^{6)}$. なお具体的な対処法について は，放射線管理部門のスタッフに確認することを勧め る. 最終的に, カセッテ内または装置内の裏側等が 污染している場合には, メーカや検出器の形式(カ セッテタイプかビルトインタイプかなど)によって，除 染を試みることができる場合やできない場合が想定 される。したがって，その状態であると判断されたと きには，メーカと相談することが重要と考える。

各ステップにおいて， RI による黒点が生じるかど うかの確認をするために約 12 時間保管することを提 案している。この理由は以下のとおりである。

·黒点が生じる場合, そのIPは, 比較的長時間, 未 使用の状態が続いていたと考えられる。

- 臨床の現場において，業務時間外 (8 時 30 分〜 17 時以外)に検証をすることが望ましい.

- 朝夕の 2 回 (7 時 30 分 $~ 8$ 時 30 分)で確認すると効 率が良い。

なお，約 12 時間に固執する必要はない。この時間 よりも長くすることについては，露光時間を長くする ことにつながるので, より黒点の発生状況を把握しや すくなると考える.

茨城県の一施設で実際に発生した黒点に対して, 提案した方法を実施した。装置は富士フイルム社製 の FCR5501plus(ビルトインタイプ)であり，4月中旬 に黒点が認められた。その画像の例をFig. 2aに示 す. 画像の上半分に多くの黒点が認められる。 そこ 
でメーカにクイックルワイパー使用の確認をしたう えで，われわれの提案に沿って污染の状況を確認し た結果, 内蔵された 2 枚の IP 両方に直接 RI が付着 していると判断できた。また，除染後のクイックルワ イパーに対して, ゲルマニウム半導体検出器を用い て分析をした結果，70×50 mmのクイックルワイパー 全体で数 $\mathrm{Bq}$ の $\mathrm{RI}\left({ }^{134} \mathrm{Cs}\right.$ と $\left.{ }^{137} \mathrm{Cs}\right)$ を含んでいた. Fig. $2 \mathrm{~b}$ に除染後の画像を示すが, 除染の状態は目視で確 認する限り，ほとんどが取り除かれているものと考え られる。また Fig. 2 に示す二つの画像を利用して除 染効果を確認すると，その効果は $90 \%$ 以上であっ た。その後，黒点の再発は認められず，IPの表面に 関しても何ら支障はないとのことである．現在，この 除染効果を他の試料も含めて定量的に解析中であ
り，詳細については続報で提出する予定である.

\section{おわりに}

各施設において発生する可能性のある黒点につい て，その発生場所の解明とその除去法に関する提案 を行った。さらに一施設において発生した黒点に対し て本方法を実施した結果，除染効果は視覚的に有効 であり，本手法の有効性が確認された。

\section{謝 辞}

鹿島労災病院放射線科の小沼洋治氏から黒点が確 認できる画像を提供していただきました。また，除染 効果の検証についてご協力いただきましたこと，感謝 いたします。

\section{参考文献}

1）首相官邸ホームページ。東日本大震災への対応，http:// www.kantei.go.jp/saigai/index.html

2) 原子力施設等の防災対策について. 原子力安全委員会 編，昭和 55 年 6 月(平成 22 年 8 月一部改定).

3）富士フイルム株式会社. FCR 画像に黒点が発生する現象 について. http://fujifilm.jp/important/article_20110322. html
4）林 裕晃，石田佳幸，柴田理尋，化学雑巾を用いた表面 污染検査の現状と他製品利用可能性の検討。放射線安全 管理学会第 8 回学術大会, 2009-12, 25.

5) 理化学辞典第 5 版。東京：岩波書店, 1998.

6) 社団法人日本アイソトープ協会編. アイソトープ法令集 (I) 2010 年版。東京：丸善株式会社，2010.

Fig. 1 IP と付属の機器に対する污染の状態と除染の方法を示すフローチャート

Fig. 2 污染したIP と除染したIP の画像の比較

これらの画像は FCR5501 で使われていた同じ番号の IP による解析結果である。露光時間は 12 時間および 15 時間であった。 